\title{
Innovation Instruments to Co-Create Needs-Based Solutions in a Living Lab
}

\section{Lotta Haukipuro, Satu Väinämö, and Pauliina Hyrkäs}

\author{
"What could be better than listening to an end user") \\ telling a potential customer about the need for our \\ solution?
}

CTO of a participant company

\begin{abstract}
This multiple case study focuses on co-creation facilitated with innovation instruments in three different environments - a school, a hospital, and an airport - in which 12 SMEs and startups developed solutions based on predefined needs of customer organizations, and where stakeholders actively participated through user involvement methods facilitated by a living lab. The article provides new knowledge regarding the benefits of the co-creation, user involvement, and use of the living lab approach within different contexts. Our findings show concrete benefits of co-creation for stakeholders such as companies, customer organizations, and end users. Based on our results, we propose a new, generic model for using innovation instruments to facilitate co-creation for the development of needs-based products and services in different service domains.
\end{abstract}

\section{Introduction}

Co-creation has been an emerging trend in the business development of companies in the 21st century (e.g. Sanders \& Stappers, 2008). Adopting the principles of the lead user method (von Hippel, 1986, 2005), the concept of co-creation was originally developed and popularized by Prahalad and Ramaswamy (2004). According to those two scholars, co-creation is the value that is generated together by a company and their customer - the customer co-constructs the service experience to suit their own context (Prahalad \& Ramaswamy, 2004). Sanders and Stappers (2008) further elaborate cocreation in relation to design development process and see co-creation as an act of collective creativity shared by two or more people. They state that, through codesign, collective creativity can be applied across the entire design development process: co-design is an explicit instance of co-creation where the creativity of designers and ordinary people meet and work together. Thus, co-creation can be seen as "a way of working" rather than as a set of certain methods (Sanders \& Stappers, 2008), and the co-creation experiences of the consumer become the very basis of value context (Lusch \& Vargo, 2006; Prahalad \& Ramaswamy, 2004). In this article, co-creation refers to the way of working to develop new solutions together with end users right from the early stages of development.

According to a recent report, $58 \%$ of businesses have piloted co-creation projects to help them innovate, $54 \%$ of businesses say that co-creation has helped improve their social impact, and $49 \%$ of businesses work with consumers on a regular basis (Hitachi, 2018). Although it seems that everyone is co-creating, actual success in co-creation depends on selecting and properly using appropriate methods and processes, because they can significantly affect project outcomes (Piller et al., 2010; Steen et al., 2011). Furthermore, small and mediumsized enterprises (SMEs) often do not have the resources, or all the needed competencies, to carry out the innovation activities (e.g., Ståhlbröst \& Holst, 2013).

These challenges highlight the importance of "living labs" as recognized providers of innovation tools and methods. As a key element of the living lab approach, co-creative innovation processes are effective and result in innovations that create value for end users (Krogstie et al., 2013; Ståhlbröst \& Holst, 2013). Hakkarainen and Hyysalo (2016) also underline the role of the organizer of co-creation, arguing that the success of real-life collaboration depends on how the co-design 


\title{
Innovation Instruments to Co-Create Needs-Based Solutions in a Living Lab
}

\author{
Lotta Haukipuro, Satu Väinämö, and Pauliina Hyrkäs
}

process has been orchestrated, facilitated, and managed. Yet, according to, for example, Leminen and Westerlund (2017) research into innovation tools and methods within the living lab approach is scarce.

The living lab approach, relying on the user innovation (von Hippel, 1976) and open innovation (Chesbrough, 2003) paradigms, has been adapted to an increasing extent in the development of new products and services. However, in the living lab literature, there is a broad variety of definitions (Leminen, 2015). We rely on Ståhlbröst's definition of a living lab as "an orchestrator of open innovation processes focusing on co-creation of innovations in real-world contexts by involving multiple stakeholders with the objective to generate sustainable value for all stakeholders focusing in particular on the end users". The common elements of a living lab include a multi-method approach, end-user engagement, multi-stakeholder participation, a real-life setting, and co-creation. The living lab approach strives for mutually valued outcomes that are results of all stakeholders being actively engaged in the process from the early phases (Malmberg \& Vaittinen, 2017). Leminen and Westerlund (2017) point out that, by using appropriate tools, living labs can significantly foster the emergence of innovation. They categorize living labs by the usage of innovation tools, and identify a living lab type that relies on both iterative, nonlinear innovation processes and customized tools. This type of living lab has prior experience and knowledge of innovation activities but wishes to keep the innovation activities flexible, which increases the likelihood of fruitful outcomes.

The aforedescribed research areas together combine a larger whole to which this article aims to contribute. The purpose of this article is to explore an innovation instrument as "a way of working" to create new solutions for the needs from different service domains. We seek to contribute to the discussion of innovation challenges by shedding light on the benefits of a facilitated innovation process with the living lab approach. Through empirical findings from three innovation instruments, we aim to show how diverse companies' solutions are efficiently co-created in different contexts, yielding improved solutions of the companies and accelerated innovation processes based on the needs of the customer organizations. Here, innovation refers here to the innovation definition comprised by Skillicorn (2016): "Executing an idea which addresses a specific challenge and achieves value for both the company and customer." By instrument, we mean "a means whereby something is achieved, performed, or furthered" (Merriam-Webster, 2018), thus innovation instrument means furthering in- novation in a facilitated process. In particular, by innovation instrument, we mean a facilitated process during which a selected group of SMEs and startup companies co-create new solutions for the specific needs of the customer organizations.

In this study, the co-creation was facilitated by Oulu Urban Living Labs (OULLabs; oullabs.fi/en) in Finland, which has provided user-centered development services for the local innovation ecosystem since 2010 (Anttiroiko, 2016; Haukipuro, 2014, 2016) and therefore has established long-term collaborations, for example, with the City of Oulu. Besides the living lab specialist services and face-to-face user involvement methods, a digital user community and user involvement tool was used for co-creation. The three cases were selected because they provide new knowledge of the improvement of innovation culture through co-creation from diverse environments and, through comparative analysis, enable forming a basis for a generic innovation instrument model. We focus on how the stakeholders, such as companies, customer organizations, and end users, perceive the benefits of co-creation through innovation instruments and how the co-creation should be facilitated.

\section{Research Design}

This study follows a multiple case study design to examine three distinct innovation instruments - "Agile Piloting", "IdeaSprint", and "Innovation Path" - which were developed in the national Six City Strategy program (6Aika, 2015) - across 12 separate company cases as research subjects. The multiple case study design enables the analysis of data within each case but also across different situations, aiming to understand the similarities or differences of the cases and increasing the validity through multiple sources of evidence (Baxter \& Jack, 2008; Gustafsson, 2017; Stake, 1995; Yin, 2003). The three individual innovation instruments are applied in within the same geographical area but focus on different service domains: education (Agile Piloting), aviation (IdeaSprint), and healthcare (Innovation Path). The instruments were targeted at SMEs and startups (hereinafter companies) to develop new solutions for the needs of the three customer organizations in Oulu, Finland: the local school, the local hospital, and the national airport operator). The domains were selected by the Six City program (6Aika, 2015), and each particular instrument was designed for its particular domain. IdeaSprint is suitable for companies as customers, Agile Piloting for a public sector customer, and Innovation Path for a healthcare customer due to a need for intensive and longer-term co-creation. 


\section{Innovation Instruments to Co-Create Needs-Based Solutions in a Living Lab}

\section{Lotta Haukipuro, Satu Väinämö, and Pauliina Hyrkäs}

The development of the companies' solutions to meet the needs of the customer organizations and end users focused on co-creation facilitated by Oulu Urban Living Labs. OULLabs is a non-profit living lab founded in 2010 at the University of Oulu, Finland, which aims to provide a diverse environment for innovation, research, development, and testing of new applications and services in an authentic environment with real users and thus to expedite competitiveness of the companies. More than 100 living lab projects have been conducted in the OULLabs environment. In particular, user involvement through different methods provided by the living lab enabled the co-creation in each innovation instrument. For example, a user involvement method used in all three innovation instruments was adapted from the World Café method introduced in 1995 by Brown and Isaacs. The idea of the method is to create a café-like setting, which enables groups of people to participate in evolving rounds of dialogue to bring forth new insights (Brown \& Isaacs, 2005). Given that the target group of each innovation instrument was a group of companies, the World Café process was modified by the living lab to ensure the utmost benefit for the devel- opment of the companies' solutions through parallel, systematic, end-user involvement in a joint event, as described in detail in the next sections.

The specific elements of the three innovation instruments are depicted in Figure 1, but all three instruments share four overall phases: 0. Preparation, 1. Selection, 2. Co-Creation, and 3. Piloting. In this article, we focus on the co-creation phase.

\section{Participant companies and customer organizations}

The 12 companies were distributed across the three innovation instruments as follows: four companies were selected to Agile Piloting, three companies to IdeaSprint, and five companies to Innovation Path. The customer organization/company decided the selection criteria and how many SMEs were selected to participate. Table 1 summarizes the 12 companies in terms of their business sector, business focus (business-to-business [B2B] versus business-to-consumer [B2C]), and context (school, hospital, or airport), and it describes the solutions that were developed using the relevant innovation instrument.

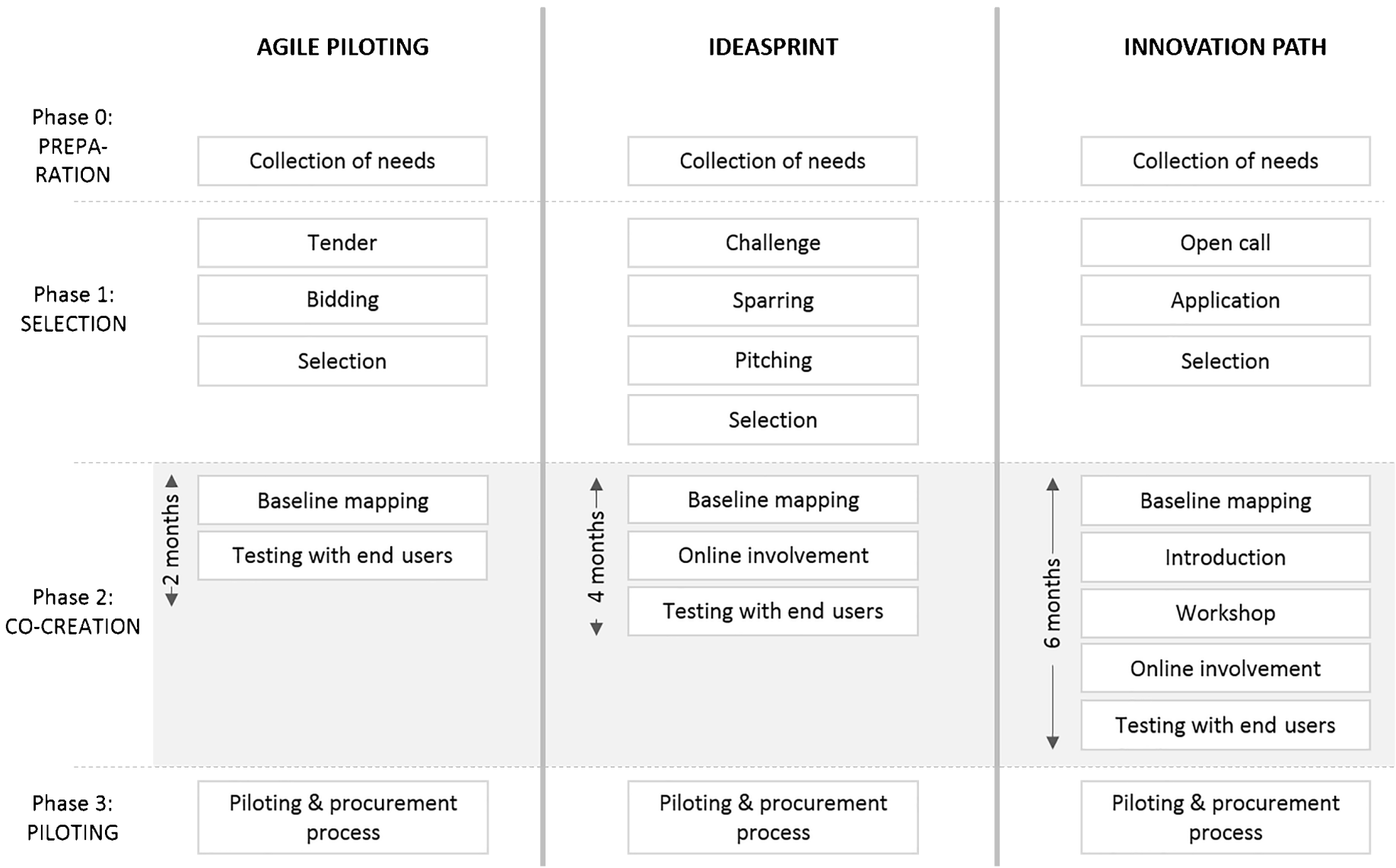

Figure 1. The elements of the three innovation instruments applied in this study 


\section{Innovation Instruments to Co-Create Needs-Based Solutions in a Living Lab}

\section{Lotta Haukipuro, Satu Väinämö, and Pauliina Hyrkäs}

Table 1. Summary of the participant companies and their solutions

\begin{tabular}{|c|c|c|c|c|c|c|c|}
\hline $\begin{array}{l}\text { Company } \\
\text { ID }\end{array}$ & $\begin{array}{l}\text { Business } \\
\text { Sector }\end{array}$ & $\begin{array}{l}\text { Business } \\
\text { Focus }\end{array}$ & Context & $\begin{array}{l}\text { Innovation } \\
\text { Instrument }\end{array}$ & Solution Description & $\begin{array}{l}\text { Solution } \\
\text { Type }\end{array}$ & $\begin{array}{l}\text { Solution } \\
\text { Maturity }\end{array}$ \\
\hline 1 & ICT & $\mathrm{B} 2 \mathrm{~B}$ & School & Agile Piloting & Navigation application & Software & Early prototype \\
\hline 5 & ICT & $\mathrm{B} 2 \mathrm{~B} / \mathrm{B} 2 \mathrm{C}$ & School & Agile Piloting & Smart sports equipment & $\begin{array}{l}\text { Product \& } \\
\text { Software }\end{array}$ & Concept \\
\hline 8 & ICT & $\mathrm{B} 2 \mathrm{C}$ & School & Agile Piloting & $\begin{array}{l}\text { Location-based mobile } \\
\text { game }\end{array}$ & Software & Early prototype \\
\hline 10 & Education & $\mathrm{B} 2 \mathrm{C}$ & School & Agile Piloting & $\begin{array}{l}\text { Problem-solving mobile } \\
\text { game }\end{array}$ & Software & Early prototype \\
\hline 4 & ICT & B2B & Airport & IdeaSprint & Service design & Service & Idea \\
\hline 9 & ICT & B2B & Airport & IdeaSprint & $\begin{array}{l}\text { Virtual guidance } \\
\text { application }\end{array}$ & Software & Concept \\
\hline 12 & $\begin{array}{l}\text { Sports } \\
\text { equipment }\end{array}$ & $\mathrm{B} 2 \mathrm{~B} / \mathrm{B} 2 \mathrm{C}$ & Airport & IdeaSprint & Portable fitness device & $\begin{array}{l}\text { Product \& } \\
\text { Software }\end{array}$ & Prototype \\
\hline 2 & ICT & $\mathrm{B} 2 \mathrm{~B} / \mathrm{B} 2 \mathrm{C}$ & Hospital & $\begin{array}{l}\text { Innovation } \\
\text { Path }\end{array}$ & $\begin{array}{l}\text { Patient self-monitoring } \\
\text { application }\end{array}$ & Software & Idea \\
\hline 3 & ICT & B2B & Hospital & $\begin{array}{l}\text { Innovation } \\
\text { Path }\end{array}$ & $\begin{array}{l}\text { Biometric identification } \\
\text { product }\end{array}$ & $\begin{array}{l}\text { Product \& } \\
\text { Software }\end{array}$ & Prototype \\
\hline 6 & ICT & B2B & Hospital & $\begin{array}{l}\text { Innovation } \\
\text { Path }\end{array}$ & $\begin{array}{l}\text { Pain measurement } \\
\text { product }\end{array}$ & $\begin{array}{l}\text { Product \& } \\
\text { Software }\end{array}$ & Idea \\
\hline 7 & $\begin{array}{l}\text { Publishing } \\
\text { (health) }\end{array}$ & B2B & Hospital & $\begin{array}{l}\text { Innovation } \\
\text { Path }\end{array}$ & $\begin{array}{l}\text { Drug management } \\
\text { application }\end{array}$ & Software & Concept \\
\hline 11 & $\begin{array}{l}\text { Healthcare } \\
\text { equipment }\end{array}$ & B2B & Hospital & $\begin{array}{l}\text { Innovation } \\
\text { Path }\end{array}$ & Mobile care station & Product & Concept \\
\hline
\end{tabular}

The three customer organizations and their development goals are described in Table 2.

\section{Innovation instrument 1: Agile Piloting}

The original agile piloting concept (Mustonen, 2015) was developed by a national organization and tested in urban development projects in Finland. The aim of the concept is to provide companies an opportunity to pilot prototypes and services in an authentic environment with real end users. In the Agile Piloting instrument referred to in this article, the aim was to find and test new solutions for a school environment by a faster process compared to the original concept. The development needs of the selected pilot school (i.e., the customer or- ganization) were identified in consultation with the school's teachers, pupils, and parents. Based on the identified needs, a public tender was opened for companies. In total, 15 tenders that described the companies' solutions were submitted. Next, an evaluation committee ranked the tenders and selected the four promising ones to enter the program. These four companies (see Table 1) were given an introduction to cocreation and user involvement, after which the companies, together with the living lab, planned the methods and tools to be used in the experiments at the school. During the process, the companies were supported to independently collect the first end-user experiences in the school. At the end of the Agile Piloting, a 


\section{Innovation Instruments to Co-Create Needs-Based Solutions in a Living Lab}

Lotta Haukipuro, Satu Väinämö, and Pauliina Hyrkäs

Table 2. Summary of the customer organizations and development goals

\begin{tabular}{lllll}
\hline $\begin{array}{l}\text { Customer } \\
\text { Organization }\end{array}$ & $\begin{array}{l}\text { Area of } \\
\text { Operations }\end{array}$ & $\begin{array}{l}\text { Service } \\
\text { Domain }\end{array}$ & $\begin{array}{l}\text { Innovation } \\
\text { Instrument }\end{array}$ & Development Goal \\
\hline $\begin{array}{l}\text { Comprehensive } \\
\text { school }\end{array}$ & Local & Education & Agile Piloting & $\begin{array}{l}\text { Solutions contributing to the creation of a comfortable, } \\
\text { safe, and exercise-enabling school environment }\end{array}$ \\
\hline Airport operator & National & Aviation & IdeaSprint & $\begin{array}{l}\text { Solutions to improve the travelling experience and increase } \\
\text { the number of satisfied passengers (e.g., smart spaces, 3D } \\
\text { solutions, smart recognition, and easy payment) }\end{array}$ \\
\hline $\begin{array}{l}\text { University } \\
\text { hospital }\end{array}$ & Local & Healthcare & $\begin{array}{l}\text { Innovation } \\
\text { Path }\end{array}$ & $\begin{array}{l}\text { Solutions that meet the needs of the children's and } \\
\text { women's division and hospital pharmacy service areas (e.g., } \\
\text { pain measurement, self-reporting, and drug loss } \\
\text { applications) }\end{array}$ \\
\hline
\end{tabular}

joint workshop was organized at the local school by the living lab. In the workshop, 21 primary school pupils and 2 primary school teachers tested each company's solution through the World Café method. Each of the four companies had their own booth for presenting and testing the solution through varying methods. Small groups of pupils spent time at each booth, familiarizing themselves with and testing the solution as the company collected data about their user experiences.

\section{Innovation instrument 2: IdeaSprint}

In recent years, a city-owned enterprise providing innovation services for local companies in Oulu has organized rapid ideation events or "sprints". The aim of these sprints is to find new solutions for real problems/needs of customer companies who share their needs in the form of challenges for developers, for example, SMEs and startups who pitch their ideas and receive immediate feedback on them. In this study, we focus on a particular instance of this event in which the co-creation phase organized by a living lab was included for the first time. It represents our second innovation instrument, IdeaSprint, which proceeded as follows.

During the event, local companies were presented with a challenge through which representatives of the national airport operator (i.e., the customer organization) introduced their development needs regarding airport services for local companies. To address this challenge, the companies ideated and planned solutions that were then discussed in a "sparring session" with the customer organization. In a pitching event, eight companies presented their solutions, of which the three best (see Table 1) were selected by the customer organization. Following the baseline mapping conducted for these three companies, the living lab supported them in the planning of end-user involvement activities. The preliminary user experiences were collected through surveys in an online tool provided by the living lab. At the end of the IdeaSprint, a joint user workshop was organized at the local airport. In the workshop, the World Café method was applied: two companies further ideated their concept with mixed user groups formed from 10 end users/passengers and four customer company representatives. One company solution of the three was mature enough to be tested in practice, enabling user-product interaction and the collection of user experiences.

\section{Innovation instrument 3: Innovation Path}

The third innovation instrument was a one-year pilot project in the healthcare sector, hereinafter Innovation Path. The objective was to create new healthcare solutions for the pre-defined needs of the local hospital (i.e., the customer organization), which would be achieved by developing and testing a process through which companies and healthcare professionals together would cocreate new hospital services. During the preparation phase, the needs were collected from two service areas of the hospital. Based on the identified needs, a call for solutions was opened to companies and developers. Altogether, 24 applications from 15 companies and two developers were received. An evaluation team of 65 professionals from healthcare, information technology (IT), and business areas was formed to rate the applications using an online tool provided by the living lab.

Five applications - two idea-level and three conceptlevel solutions (see Table 1) - were selected to enter the Innovation Path to be further developed through different co-creation methods and tools tailored on the basis 


\section{Innovation Instruments to Co-Create Needs-Based Solutions in a Living Lab}

Lotta Haukipuro, Satu Väinämö, and Pauliina Hyrkäs

of their maturity and needs. Co-creation activities were organized in cooperation with the hospital innovation personnel to engage suitable healthcare professionals to participate in the co-creation activities. The detailed needs of the hospital and the aim of co-creation were introduced to the selected companies, after which the co-creation with professionals took place in form of different activities. More than 60 healthcare and IT professionals participated in the co-creation. First, a conversational workshop was organized, during which the modified World Café method was used to collect initial feedback from the groups of healthcare and IT specialists. Next, each concept was further developed through online methods such as a survey, online discussion, or user diary, depending on the nature of the solution. Finally, individual user-testing sessions were carried out by pairs of users interacting with the companies' prototypes in a hospital testing environment. In the final evaluation event, each company presented their solutions to an evaluation group of over 20 healthcare professionals from different fields, who then made a decision on further cooperation.

\section{Data Collection}

Research data were collected through multiple methods, which is typical for qualitative case studies (Eisenhardt, 1989). Table 3 provides an overview of the primary and ancillary research data used in this study. The primary data mainly consists of the key informants' semi-structured in-depth interviews regarding each innovation instrument: the company representatives of the 12 case companies, the customer organization representatives and professionals, and the facilitators of each innovation instrument. The interviews were audio recorded and transcribed. The transcripts were explored multiple times to develop in-depth understanding. In addition, the living lab researchers were involved in the processes of all three innovation instruments by observing and taking notes. Ancillary data comprise various materials such as companies' applications, feedback discussions, and questionnaires used for different purposes. The qualitative cross-case analysis was conducted for comparison of the cases to increase the explanatory power of the study (Eisenhardt 1989; Halinen \& Törnroos 2005) and to enable the triangulation of data in order to increase the reliability of the study (Denzin 1973; Eisenhardt, 1989). The principle in the data analysis was to systematically seek connections, recurrences, and alterations from the primary and ancillary data and draw out patterns.

\section{Methods of user involvement}

Table 4 summarizes the methods of user involvement used in the three innovation instruments. The two methods used in all three cases were i) discussion/sparring, which was conducted in individual meetings with each participant company in the beginning of the process of each case, and ii) the modified World Café method used in the workshops. The other methods, such as online methods, user testing, and the focus group were not used in all cases, mainly due to the different durations of the cases but also due to the nature and maturity of the companies' solutions. In each case,

Table 3. Number of instances and types of research data collected for each innovation instrument

\begin{tabular}{lccc}
\hline Data Type & Agile Piloting & IdeaSprint & Innovation Path \\
\hline Primarydata & 4 & 9 & 30 \\
$\quad$ Interviews & 4 & 0 & 4 \\
Feedback survey & 14 & & \\
\hline Ancillarydata & 8 & 8 & 24 \\
Applications & 0 & 8 & 12 \\
Feedback in discussions & 23 & 14 & 31 \\
Feedback using online tool & & 0 & 20 \\
End-user feedback survey & &
\end{tabular}




\section{Innovation Instruments to Co-Create Needs-Based Solutions in a Living Lab}

Lotta Haukipuro, Satu Väinämö, and Pauliina Hyrkäs

Table 4. User involvement methods provided by the living lab

\begin{tabular}{|c|c|c|c|c|}
\hline Method & Description & Agile Piloting & IdeaSprint & Innovation Path \\
\hline Discussion/sparring & Meetings with companies & $\mathrm{x}$ & $\mathrm{x}$ & $\mathrm{x}$ \\
\hline World Café & Testing and user insight tour in groups & $\mathrm{x}$ & $\mathrm{x}$ & $\mathrm{x}$ \\
\hline Online discussion & Interactive discussion within a group of users & & & $\mathrm{x}$ \\
\hline Online survey & Questionnaire delivered with online tool & & $\mathrm{x}$ & $\mathrm{x}$ \\
\hline Online diary & Online user diary (private) & & & $\mathrm{x}$ \\
\hline User testing & Testing of the solution in an authentic setting & & & $\mathrm{x}$ \\
\hline Focus group & Feedback discussion for professionals & & & $\mathrm{x}$ \\
\hline
\end{tabular}

the methods were tailored to the groups of companies (e.g., a joint workshop) and for each company separately depending on the maturity level and nature of the solution, for example. The goal was to find the most appropriate way to enhance the further development of the solutions. For example, in the joint workshops, each company applied a different type of user involvement method, such as user testing, a questionnaire, or a focus group discussion according to the plan. Moreover, online methods (e.g., surveys, online discussions, and user diaries) were generally aimed at concept-level solutions based on earlier experiences (Haukipuro et al., 2016).

\section{Findings and Discussion}

In general, the participant companies perceived the cocreation activities provided by the living lab beneficial, frequently describing the overall process as "easy" and "well organized". According to the findings, the innovation instruments were particularly beneficial for B2B companies as they enabled direct contact with the large and desirable customer organizations, which would otherwise have been difficult for them to reach. Moreover, the IdeaSprint companies highlighted the commitment of the customer organization and appreciated that there was "an atmosphere of innovating together" during the whole process. The findings are presented in more detail in the subsections that follow.

\section{Co-creation activities}

The modified World Café method was a liked and suitable way to collect feedback from end users, regardless of the solution's maturity level. The method was used in the workshops organized in different phases: in the Innovation Path, the workshop was held already in the beginning of the process, when the companies did not have concrete plans or prototypes to discuss. Therefore, the workshop was rather a conversational, interactive event allowing the hospital professionals from different fields to meet with each company in groups. In the IdeaSprint and Agile Piloting, similar workshops were organized in the later phases of the process, when companies had a prototype or a testable product. Regarding the IdeaSprint workshop organized at the airport (Figure 2), both the companies and the customer organization thought it as a success. Particularly valuable for them were the mixed groups: in each group, there were end users/passengers and airport operator representatives, which enabled direct communication between the company, service provider, and end users. As one company representative put it:

"What could be better than listening to an end user telling a potential customer about the need for our solution?" (Company \#9)

In another example, a representative of the IdeaSprint customer organization did not have particularly high expectations about the workshop organized at the airport it; rather, they had a skeptical attitude based on earlier experiences of workshop outcomes. However, the successful workshop totally changed the representative's view about the end-user involvement. Another representative also regarded the workshop as a great event, pointing out the importance of involving the end users: 


\section{Innovation Instruments to Co-Create Needs-Based Solutions in a Living Lab}

\section{Lotta Haukipuro, Satu Väinämö, and Pauliina Hyrkäs}
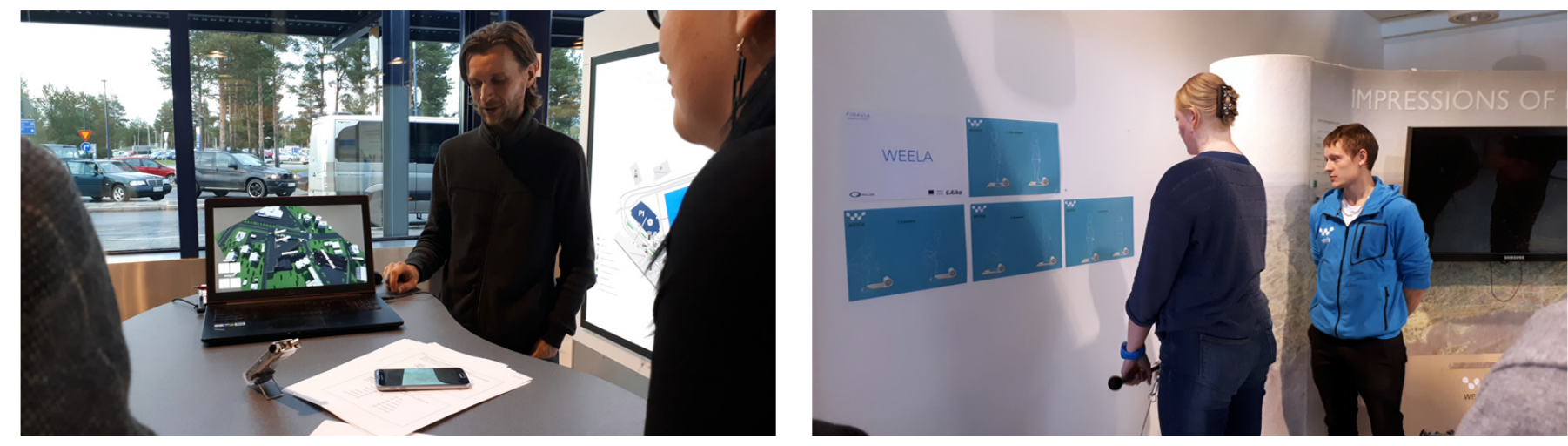

Figure 2. Co-creating company solutions at the airport during the IdeaSprint

"It was the part of the process that exceeded the expectations most, and it was a good session, really worth participating in." (Customer organization representative \#1)

In the Agile Piloting, given that there were user-involvement features built into the companies' solutions, the co-creation activity organized by the living lab focused on the workshop implemented with the modified World Café method at the local school (Figure 3). In addition, each company applied their own type of methods at their booths (Table 5). The findings show that companies regarded the workshop outcome as useful and end users also enjoyed participating in the workshop.

In the Innovation Path (Figure 4), the initial feedback was collected after various co-creation events using feedback forms and, later, during interviews. Overall, the hospital professionals were enthusiastic about new ways of enabling them to provide their expertise for the development of the companies' solutions. According to the professionals' feedback, the different events were successful, with typical descriptions being "great" and "inspiring". In particular, the conversational nature of the events was considered very beneficial. Although the strict hierarchy of the hospital environment was apparent in the Innovation Path process, the co-creation workshop participants, regardless of their work role, felt they could speak freely and express their real opinions on the matters:

"Although it demands courage to participate, it is important - otherwise, we nurses cannot be heard." (A hospital professional)

The professionals emphasized their involvement in the early phase as a way to ensure that the development of the solutions is on the right track. The most liked activity among the hospital professionals was the testing session as, for the first time, they saw concrete prototypes and could test them in practice. The user testing of each company solution was organized as paired testing with four to five pre-selected pairs of professionals in a hospital test environment (Figure 5). The living lab user researcher guided the session with a precise assignment,
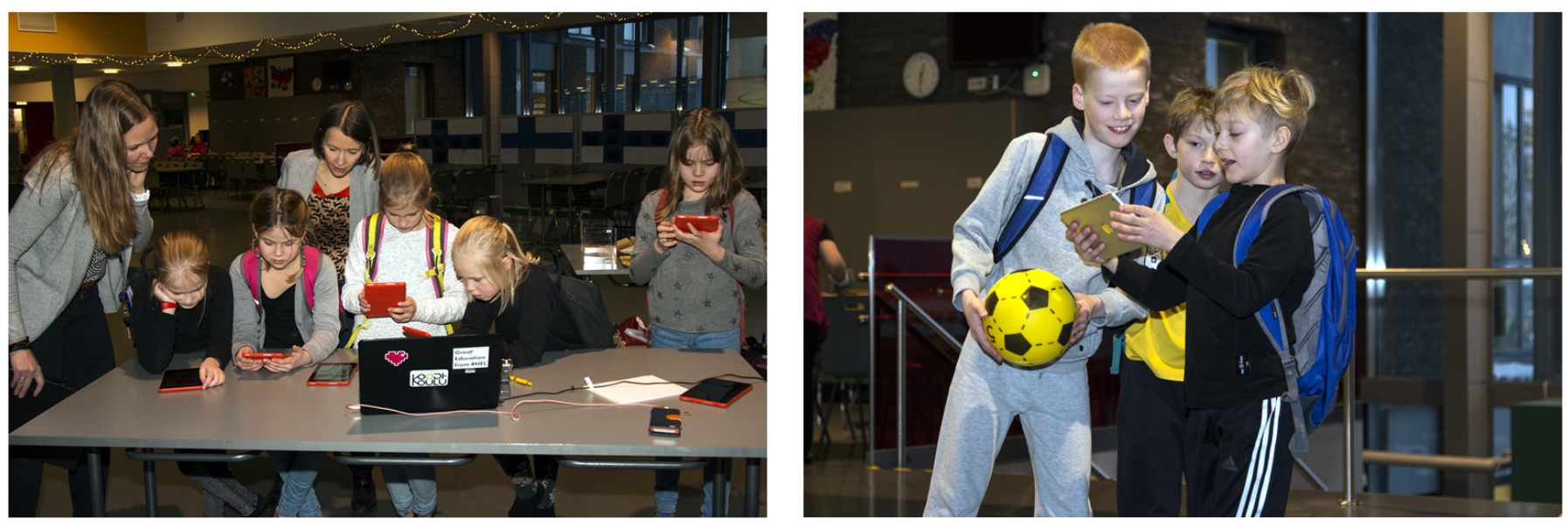

Figure 3. Pupils test the companies' solutions at their school 


\section{Innovation Instruments to Co-Create Needs-Based Solutions in a Living Lab}

Lotta Haukipuro, Satu Väinämö, and Pauliina Hyrkäs
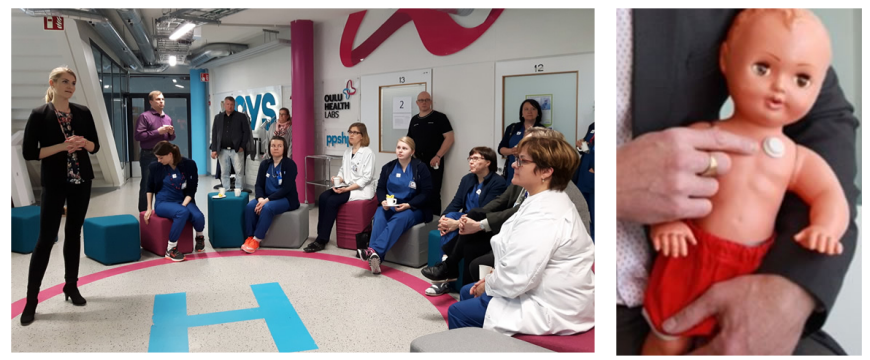

Figure 4. Hospital professionals (left) and an Innovation path company solution (right)

but observed in the background during the actual testing. The paired testing setup worked well and, according to the participants, the testing situation was "interesting" and "felt realistic".

\section{Online methods}

An online user involvement tool was used in two cases (Table 4). In the IdeaSprint, all three finalist companies conducted a survey about their concept using the online tool. The aim of the survey was to find out the preliminary thoughts of the end users. According to one company, the online tool was very beneficial as the survey results formed the basis for discussions in the workshop at the airport. Two companies appreciated the combination of online tools and traditional workshops, whereas one company considered user testing as the best way to collect user experiences. Considering the Innovation Path instrument, the findings revealed an adoption barrier to online tools, which were not that familiar to all hospital professionals. The online tool was used two times during the process: for the evaluation of the companies' applications and for the evaluation of the companies' concepts through a survey, an online discussion, or a user diary. There was also a clear division in how the companies experienced the online tool. The online involvement revealed that one company's solution had not developed towards concept phase but was rather still an idea, which greatly affected the online feedback collection. Thus, the professionals' feedback gathered through online methods was not so beneficial for the development of this solution. The other companies collected professionals' feedback through the online discussion and surveys at the online tool, but their experiences ranged from "quite useless" to "beneficial".

\section{Impact of the end-user feedback on the solutions}

All IdeaSprint companies could name concrete impacts of the end-user feedback. They pointed out that the user feedback confirmed their previous thoughts or plans, brought up issues that they had not detected earlier:

"We found out what (features) our solution should include and what the entity the offer for piloting would comprise." (Company \#9)

Also, all the Innovation Path companies reported having made some concrete changes in their solutions based on feedback from the hospital professionals (both medical and IT). The feedback on one solution in particular had a tremendous impact: the original plan was totally changed, including the size, appearance, and use logic of the product. The companies also reported the impact being tangible through small changes in solutions and, for example, the discovery of use scenarios related issues during the testing session:

"[The solution] has changed completely thanks to the feedback from professionals - it is now really a different type of solution. If I had done it alone in the garage, without the client beside me, it would have failed badly." (Company \#6)
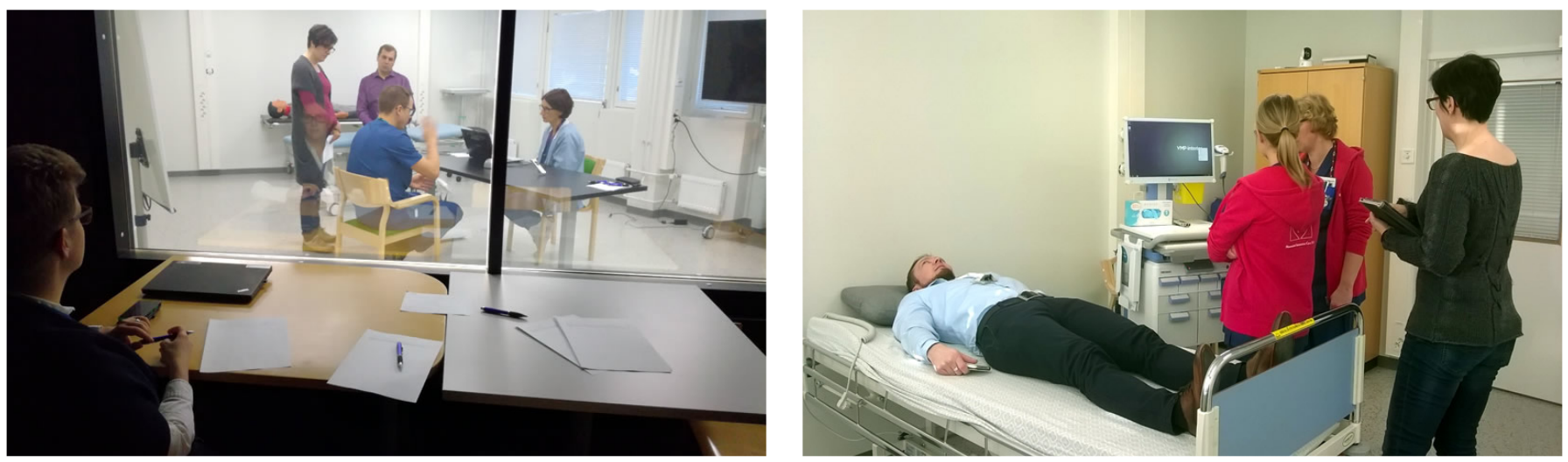

Figure 5. User testing sessions of two Innovation Path solutions at the hospital 


\section{Innovation Instruments to Co-Create Needs-Based Solutions in a Living Lab}

Lotta Haukipuro, Satu Väinämö, and Pauliina Hyrkäs

In the Agile Piloting, the few companies that by themselves actively collected feedback from end users from the earliest phase benefited the most and could utilize this feedback to improve their solutions during the process. For the rest, the impact of the feedback confirmed the companies' previous thoughts. However, the overall experiences of the Agile Piloting companies regarding the whole process were positive. They reported having gained valuable user experience and customer understanding to be exploited in their future development. The fast, non-bureaucratic experiment enabled fast decision making about whether to continue the development of the solution or to quit it:

"We learned that the experiment is worth it-and that end users know better what they want than the company that develops the solutions." (Company \#8)

\section{Role of the facilitator}

Based on the empirical findings, the role of the living lab as organizer, manager, and facilitator of the co-creation in all the cases was crucial. The participant companies valued the support from the living lab in the preparation and organization of the co-creation activities. According to several companies, the process was made "smooth" and "easy" for them because all practical and resource-demanding arrangements such as participant recruitment were taken care of by the living lab. Thus, the stakeholders considered the workshops with the World Café method as a "fruitful" and "pleasant", mainly thanks to successful pre-arrangements and an "encouraging" and "inspiring" atmosphere. As one company representative put it:

"We could focus on substance because the other aspects were taken care of by the organizer." (Company \#4)

Moreover, the expertise of the living lab researchers was highly appreciated. For example, according to the hospital professionals, it made the co-creation events effective and meaningful. In particular, the hospital professionals regarded the arrangements and facilitation of the user-testing sessions as "great", pointing out that there were no co-creation procedures or related expertise in their organization. The living lab's support in the sparring and in preparing the end-user involvement (e.g., online) was also mentioned as important because the small companies did not have the resources or competences to properly organize such activities. Overall, the companies and customer organizations estimated that, given the support and services provided by the liv- ing lab, they "saved a lot of resources". From the point of view of the customer organizations, the co-creation facilitated by the living lab was the most important element to achieve successful results.

The overall outcomes obtained by each company in each three innovation instruments are described in Table 5.

\section{The model of innovation instrument with co-creation}

Based on the findings, a generic model of innovation instrument with co-creation was synthetized from the three innovation instruments explored in this study. Figure 6 depicts the new model, which includes three phases: preparation, co-creation, and piloting. The preparation phase contains the selection of a customer organization. In selecting a customer organization, the context should be interesting and the promise should be sufficiently attractive - it must be more than simply a promise of further discussions, as was the case with Innovation Path. For example, in IdeaSprint, the companies were promised a paid pilot. Based on the findings, the co-creation phase and facilitated user involvement has been extended to cover the needs collection with the end users of the customer organization. In addition, findings show that co-creation should also cover the selection of SMEs in terms of interactions between stakeholders to ensure the mutual understanding of the development need and the maturity of the solution. The maturity level of each company's solution is assessed, and the suitable "innovation path" and methods tailored to the companies' needs. Tailoring requires strong user involvement knowledge from the facilitator. The co-creation activities are conducted for the group companies whose solutions are at the same maturity level, which saves the resources of the all stakeholders involved and accelerates the innovation process, however, taking into account the individual needs and fit of the method for each company. At the end of the co-creation phase, the company solutions are tested with end users, after which they should be ready for further steps such as piloting in customer organizations or procurement. Ideas and concept-level solutions require more effort and co-creation activities compared to early prototypes. Stakeholders involved for each phase vary from customer organization and facilitator in the preparation and piloting phases to the broader group of stakeholders in the co-creation phase. In particular, the role of the facilitator (e.g., the living lab) is crucial from the collection of the development needs to the piloting to ensure the proceeding and successful outcome of the process. 


\section{Innovation Instruments to Co-Create Needs-Based Solutions in a Living Lab Lotta Haukipuro, Satu Väinämö, and Pauliina Hyrkäs}

Table 5. Outcome of the innovation instruments

\begin{tabular}{|c|c|c|c|c|c|c|}
\hline $\begin{array}{l}\text { Company } \\
\text { ID }\end{array}$ & $\begin{array}{l}\text { Innovation } \\
\text { Instrument }\end{array}$ & $\begin{array}{l}\text { Solution } \\
\text { Description }\end{array}$ & $\begin{array}{l}\text { Solution } \\
\text { Maturity }\end{array}$ & Co-CreationActivities & Outcomes & Further Actions \\
\hline 1 & $\begin{array}{l}\text { Agile } \\
\text { Piloting }\end{array}$ & $\begin{array}{l}\text { Navigation } \\
\text { application }\end{array}$ & $\begin{array}{l}\text { Early } \\
\text { prototype }\end{array}$ & $\begin{array}{l}\text { - Involvement of parents } \\
\text { - Sparring with living lab } \\
\text { - User testing and questionnaire at } \\
\text { workshop }\end{array}$ & $\begin{array}{l}400+\text { downloads, } \\
\text { new use case }\end{array}$ & $\begin{array}{l}\text { Piloting } \\
\text { continued at } \\
\text { school }\end{array}$ \\
\hline 5 & $\begin{array}{l}\text { Agile } \\
\text { Piloting }\end{array}$ & $\begin{array}{l}\text { Smart sports } \\
\text { equipment }\end{array}$ & Concept & $\begin{array}{l}\text { - Testing and ideation at school } \\
\text { - Sparring with living lab } \\
\text { - User testing and rapid feedback } \\
\text { at workshop }\end{array}$ & $\begin{array}{l}\text { Proof of concept } \\
\text { and reference }\end{array}$ & $\begin{array}{l}\text { Use for promotion } \\
\text { of sensor } \\
\text { technology }\end{array}$ \\
\hline 8 & $\begin{array}{l}\text { Agile } \\
\text { Piloting }\end{array}$ & $\begin{array}{l}\text { Location- } \\
\text { based } \\
\text { mobile game }\end{array}$ & $\begin{array}{l}\text { Early } \\
\text { prototype }\end{array}$ & $\begin{array}{l}\text { - Prototyping at school } \\
\text { - Sparring with living lab } \\
\text { - Testing and focus group at } \\
\text { workshop }\end{array}$ & $\begin{array}{l}\text { No interest by end } \\
\text { users, technical } \\
\text { challenges }\end{array}$ & $\begin{array}{l}\text { Cancellation of } \\
\text { product } \\
\text { development }\end{array}$ \\
\hline 10 & $\begin{array}{l}\text { Agile } \\
\text { Piloting }\end{array}$ & $\begin{array}{l}\text { Problem- } \\
\text { solving } \\
\text { mobile game }\end{array}$ & $\begin{array}{l}\text { Early } \\
\text { prototype }\end{array}$ & $\begin{array}{l}\text { - Prototyping at school } \\
\text { - Sparring with living lab } \\
\text { - Testing and survey at workshop }\end{array}$ & $\begin{array}{l}\text { Change of } \\
\text { features, insight } \\
\text { for business } \\
\text { development }\end{array}$ & Procurement \\
\hline 4 & IdeaSprint & $\begin{array}{l}\text { Service } \\
\text { design }\end{array}$ & Idea & $\begin{array}{l}\text { - Sparring with customer } \\
\text { organization and living lab } \\
\text { - Survey for end users } \\
\text { - Co-design at workshop }\end{array}$ & New service & Piloting at airport \\
\hline 9 & IdeaSprint & $\begin{array}{l}\text { Virtual } \\
\text { guidance } \\
\text { application }\end{array}$ & Concept & $\begin{array}{l}\text { - Sparring with customer } \\
\text { organization and living lab } \\
\text { - Survey for end users } \\
\text { - Focus group at workshop }\end{array}$ & $\begin{array}{l}\text { Focusing on the } \\
\text { right features }\end{array}$ & $\begin{array}{l}\text { Further } \\
\text { development }\end{array}$ \\
\hline 12 & IdeaSprint & $\begin{array}{l}\text { Portable } \\
\text { fitness } \\
\text { device }\end{array}$ & Prototype & $\begin{array}{l}\text { - Sparring with customer } \\
\text { organization and living lab } \\
\text { - Survey for end users } \\
\text { - UX testing at workshop }\end{array}$ & $\begin{array}{l}\text { Changes in the } \\
\text { software, usage } \\
\text { idea, and } \\
\text { instructions }\end{array}$ & Piloting at airport \\
\hline 2 & $\begin{array}{l}\text { Innovation } \\
\text { Path }\end{array}$ & $\begin{array}{l}\text { Patient self- } \\
\text { monitoring } \\
\text { application }\end{array}$ & Idea & $\begin{array}{l}\text { - Sparring with living lab } \\
\text { - Workshop with professionals } \\
\text { - Concept evaluation in online tool } \\
\text { - Focus group }\end{array}$ & $\begin{array}{l}\text { Field-specific } \\
\text { knowledge of } \\
\text { requirements }\end{array}$ & $\begin{array}{l}\text { No action } \\
\text { (immaturity of the } \\
\text { solution) }\end{array}$ \\
\hline 3 & $\begin{array}{l}\text { Innovation } \\
\text { Path }\end{array}$ & $\begin{array}{l}\text { Biometric } \\
\text { identificatio } \\
\text { n product }\end{array}$ & Prototype & $\begin{array}{l}\text { - Sparring with living lab } \\
\text { - Workshop with professionals } \\
\text { - Concept evaluation in online tool } \\
\text { - User testing }\end{array}$ & $\begin{array}{l}\text { New product idea, } \\
\text { small } \\
\text { improvements }\end{array}$ & $\begin{array}{l}\text { No action } \\
\text { (unsuitability of } \\
\text { the technology) }\end{array}$ \\
\hline 6 & $\begin{array}{l}\text { Innovation } \\
\text { Path }\end{array}$ & $\begin{array}{l}\text { Pain } \\
\text { measureme } \\
\text { nt product }\end{array}$ & Idea & $\begin{array}{l}\text { - Sparring with living lab } \\
\text { - Workshop with professionals } \\
\text { - Focus group }\end{array}$ & $\begin{array}{l}\text { Radical change of } \\
\text { size, layout, and } \\
\text { functionality }\end{array}$ & $\begin{array}{l}\text { Research co- } \\
\text { operation and } \\
\text { clinical trial in } \\
\text { hospital }\end{array}$ \\
\hline 7 & $\begin{array}{l}\text { Innovation } \\
\text { Path }\end{array}$ & $\begin{array}{l}\text { Drug } \\
\text { managemen } \\
\text { t application }\end{array}$ & Concept & $\begin{array}{l}\text { - Sparring with living lab } \\
\text { - Workshop with professionals } \\
\text { - Concept evaluation in online tool } \\
\text { - User testing }\end{array}$ & $\begin{array}{l}\text { Improvements for } \\
\text { the concept }\end{array}$ & $\begin{array}{l}\text { Further co- } \\
\text { creation in } \\
\text { hospital }\end{array}$ \\
\hline 11 & $\begin{array}{l}\text { Innovation } \\
\text { Path }\end{array}$ & $\begin{array}{l}\text { Mobile care } \\
\text { station }\end{array}$ & Concept & $\begin{array}{l}\text { - Sparring with living lab } \\
\text { - Workshop with professionals } \\
\text { - Concept evaluation in online tool } \\
\text { - User testing }\end{array}$ & New product & $\begin{array}{l}\text { Piloting at } \\
\text { hospital }\end{array}$ \\
\hline
\end{tabular}




\section{Innovation Instruments to Co-Create Needs-Based Solutions in a Living Lab}

Lotta Haukipuro, Satu Väinämö, and Pauliina Hyrkäs

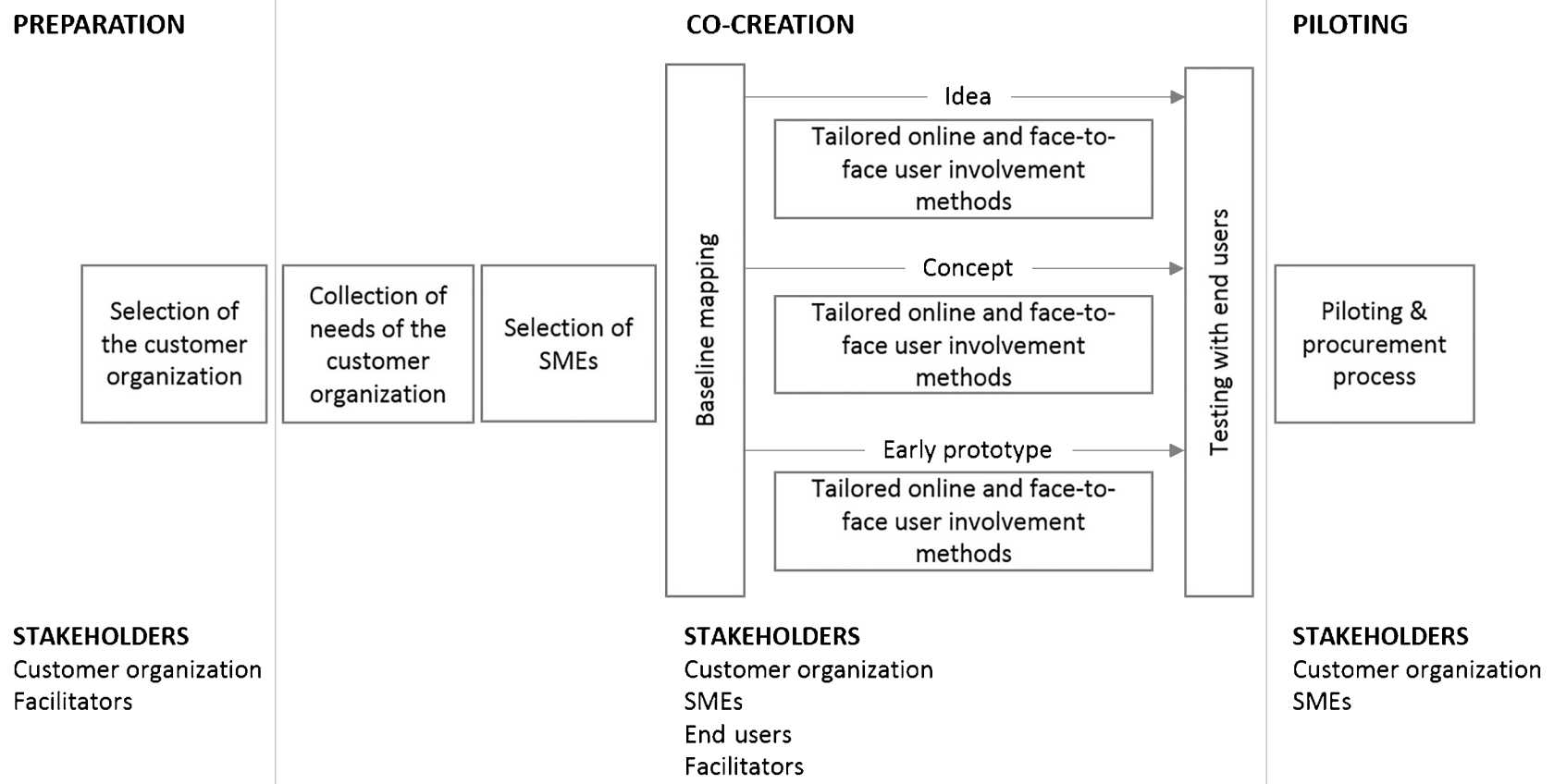

Figure 6. The resulting model of innovation instrument including co-creation

\section{Conclusion}

The purpose of this article was to increase knowledge of the benefits of co-creation in a facilitated process in different contexts. Our empirical findings indicate that cocreation can have a significant role in the development of needs-based solutions. Through a variety of living lab user involvement methods tailored to the needs of the companies (Leminen \& Westerlund, 2017), promising results were achieved both for the companies and customer organizations as well as for the end users. In this study, the co-creation was implemented in an efficient manner through innovation instruments for the groups of selected SMEs and startups, instead of separate time- and resource-consuming activities. Moreover, the suitability of the co-creation activities was ensured by tailoring them according to the maturity level of the 12 solutions. The companies were guided through the facilitated process in each innovation instruments. The outcomes indicate the potential of innovation instruments with co-creation in order to efficiently develop new solutions that meet the end-users' needs. Hence, a generic model for innovation instrument with co-creation was formed.

In line with previous research, for example by Steen and colleagues (2011), our findings show that, by involving end users in the early stage of the solution development, companies receive concrete benefits such as valuable insight regarding their ideas and concepts, which they can then take into account in the development. In the later phase, user testing provided information of the usage and revealed issues to be considered in the further development of the solutions. The findings based on the three different innovation instruments show that co-creation activities, irrespective of the nature of the development environment (e.g., school, hospital, or airport) were regarded as an effective way to develop user-friendly solutions that meet the needs of the customer organization. Although the use of online methods distributed the opinions, the combination of the online and face-to-face methods was seen as fruitful. Overall, the findings indicate the significance of the living lab as the organizer and facilitator of co-creation activities, largely due to the lack of resources and competences in companies (Sanders \& Stappers, 2008; Ståhlbröst, 2013). Due to the varying timeframe of the innovation instruments and the amount of the co-creation activities, the most powerful impact was obtained in the longest innovation instrument, the Innovation Path. However, the two shorter innovation instruments yielded promising results as well.

To summarize, the main benefits of innovation instruments with co-creation facilitated by the living lab for participant companies were: i) an easy, tailored, and low-resource-demanding, multi-method co-creation process; ii) a co-operation opportunity with a desirable 


\section{Innovation Instruments to Co-Create Needs-Based Solutions in a Living Lab}

\section{Lotta Haukipuro, Satu Väinämö, and Pauliina Hyrkäs}

customer; iii) direct interaction between company, customer and end users during the process; iv) obtained knowledge and experience of the impact of co-creation and end-user involvement; v) improved, co-created products meeting the needs of the end-users and customers; and vi) a valuable reference and use case to support new business of the companies. Continued cooperation in terms of piloting or other activities with the customer organization was an outcome in many cases, but other cases resulted in the cancellation of product development, which may have prevented future loss of investment by the companies. From the perspective of the customer organizations, an accelerated innovation process of pre-defined products and services was gained, resulting in company solutions that meet the needs of customer organization and their end users.

\section{About the Authors}

Lotta Haukipuro, MSc (Econ), is a doctoral candidate at the Oulu Business School at the University of Oulu in Finland. Her PhD research focuses on user involvement through living lab approach in different contexts. She has participated in several international and national innovation, research and development projects as a specialist of living lab and user involvement methods, and has administered a user community and user involvement tool since 2011.

Satu Väinämö, MSc (Tech), is a User Research Expert and Project Manager at the University of Oulu in Finland. She has comprehensive experience of leading international projects, managing and creating user interface designs, and defining innovation processes. Her career includes over 15 years in the ICT industry in several leadership and user-experience design positions. She has led more than 100 development activities within Oulu Urban Living Labs, where she is currently in charge of projects related to innovation and living labs.

Pauliina Hyrkäs, BHSc (Health Management), Northern Ostrobothnia Hospital District (NOHD), Finland, has worked in local, national, and international healthcare sector projects as a project manager, a coordinator, and a designer. With her project team, she developed nationally applicable innovation process for Finnish University Hospitals as well as the Development and Innovation Process for the NOHD. Currently, she is starting up the innovation activities at the Oulu University Hospital (OYS), designing the innovation process for the Future Hospital OYS 2030 and for the innovation ecosystem around the OYS as well as the healthcare co-creation process to be utilized at the European Union level.

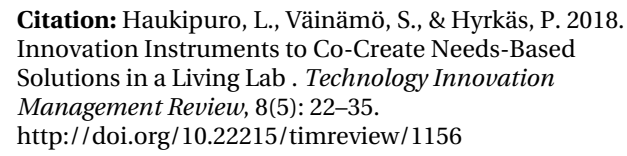

Citation: Haukipuro, L., Väinämö, S., \& Hyrkäs, P. 2018. Innovation Instruments to Co-Create Needs-Based Solutions in a Living Lab . Technology Innovation Management Review, 8(5): 22-35.

http://doi.org/10.22215/timreview/1156

Keywords: innovation instrument, innovation process, living lab, co-creation, SME, startup, user involvement (cc) BY 


\section{Innovation Instruments to Co-Create Needs-Based Solutions in a Living Lab}

\section{Lotta Haukipuro, Satu Väinämö, and Pauliina Hyrkäs}

\section{References}

6Aika. 2015. The Six City Strategy - Open and Smart Services. Finland: 6Aika, Forum Virium Helsinki, Ministry of Employment and the Economy. https://6aika.fi/wp-content/uploads/2015/11/6Aikastrategia_p\%C3\%A4ivitys_2015_EN.pdf

Anttiroiko, A.-V. 2016. City-as-a-Platform: The Rise of Participatory Innovation Platforms in Finnish Cities. Sustainability, 8(9): 922. https://doi.org/10.3390/su8090922

Baxter, P., \& Jack, S. 2008. Qualitative Case Study Methodology: Study Design and Implementation for Novice Researchers. The Qualitative Report, 13(4): 544-559.

Benson, S. 2013. Co-Creation 101: How to Use the Crowd as an Innovation Partner to Add Value to Your Brand. Vision Critical, October 21, 2013. Accessed May 15, 2018:

https://www.visioncritical.com/cocreation-101/

Brown, J., \& Isaacs, D. 2005. The World Café: Shaping Our Futures Through Conversations That Matter. San Francisco, CA : BerrettKoehler Publishers.

Chesbrough, H. 2003. Open Innovation: The New Imperative for Creating and Profiting from Technology. Boston: Harvard Business School Press.

Denzin, N. K. 1973. The Research Act (3rd ed.). Chicago, IL: Aldine.

Eisenhardt, K. M. 1989. Building Theories from Case Study Research. Academy of Management Review, 14(4): 532-550. https://doi.org/10.5465/amr.1989.4308385

Gustafsson, J. 2017. Single Case Studies vs. Multiple Case Studies: A Comparative Study. Dissertation. Halmstad, Sweden: Halmstad University.

http://urn.kb.se/resolve?urn=urn:nbn:se:hh:diva-33017

Hakkarainen, L., \& Hyysalo, S. 2016. The Evolution of Intermediary Activities: Broadening the Concept of Facilitation in Living Labs. Technology Innovation Management Review, 6(1): 45-58. https://timreview.ca/article/960

Halinen, A., \& Törnroos, J. 2005. Using Case Methods in the Study of Contemporary Business Networks. Journal of Business Research, 58(9): 1285-1297.

https://doi.org/10.1016/j.jbusres.2004.02.001

Haukipuro, L., Väinämö, S., \& Arhippainen, L. 2014. Living Lab as OneStop-Shop in the Development of Public Services. Interdisciplinary Studies Journal: A Special Issue on Smart Cities, 3(4): 157-162.

Haukipuro, L., Pakanen, M., \& Väinämö, S. 2016. Online User Community for Efficient Citizen Participation. Proceedings of the 20th International Academic Mindtrek Conference (ACM): 78-85. New York, NY: Academic Mindtrek.

http://dx.doi.org/10.1145/2994310.2994341ACM

Hitachi. 2018. What Is 'Co-Creation' and What Are the Benefits for Companies? The Telegraph, January 26, 2018. Accessed May 15, 2018:

http://www.telegraph.co.uk/business/social-innovation/benefitsof-co-creation/

Krogstie, J., Ståhlbröst, A., Holst, M., Gudmundsdottir, A., Olesen, A., Braskus, L., Jelle, T., \& Kulseng, L. 2013. Using a Living Lab Methodology for Developing an Energy Savings Solutions. Paper presented at the 19th Americas Conference on Information Systems, August 15-17, 2013, Chicago, IL.
Leminen, S. 2015. Living Labs as Open Innovation Networks Networks, Roles and Innovation Outcomes. Doctoral dissertation. Espoo, Helsinki: Aalto University School of Science, Department of Industrial Engineering and Management.

Leminen, S., \& Westerlund, M. 2017. Categorization of Innovation Tools in Living Labs. Technology Innovation Management Review, 7(1): 15-25.

http://timreview.ca/article/1046

Lusch, R. P., \& Vargo, S. L. (Eds.). 2006. The Service Dominant Logic of Marketing: Dialog, Debate and Directions. Armonk, NY: M.I. Sharpe.

Malmberg, K., \& Vaittinen, I. (Eds.) 2017. What Is a Living Lab? In Living Lab Methodology Handbook: 10-12. U4IoT Consortium. http://doi.org/10.5281/zenodo.1146321

Merriam-Webster. 2018. Definition of "instrument". MerriamWebster. Accessed May 15, 2018:

https://www.merriam-webster.com/dictionary/instrument

Mustonen, V. 2015. Creating a Smart City Vision in a Living Lab - Case Study of Smart Kalasatama Vision-building Process. Paper presented at ENoLL Open LivingLab Days, August 24-28, 2015, Istanbul, Turkey.

Piller, F. T., Ihl, C., \& Vossen, A. 2010. A Typology of Customer CoCreation in the Innovation Process. SSRN, December 29, 2010. https://dx.doi.org/10.2139/ssrn.1732127

Prahalad, C. K., \& Ramaswamy, V. 2004. Co-Creating Unique Value With Customers. Strategy and Leadership, 21(3): 4-9. https://doi.org/10.1108/10878570410699249

Sanders, E. B.-N., \& Stappers, P. J. 2008. Co-Creation and the New Landscapes of Design. CoDesign, 4(1): 5-18. http://dx.doi.org/10.1080/15710880701875068

Skillicorn, N. 2016. What Is Innovation? 15 Experts Share Their Innovation Definition. Idea to Value, March 18, 2016. Accessed May 15, 2018:

https://www.ideatovalue.com/inno/nickskillicorn/2016/03/innova tion-15-experts-share-innovation-definition/

Stake, R. E. 1995. The Art of Case Study Research. Thousand Oaks, CA: Sage.

Steen, M., Manschot, M., \& De Koning, N. 2011. Benefits of Co-Design in Service Design Projects. International Journal of Design, 5(2): 53-60.

Ståhlbröst, A. 2013. A Living Lab as a Service: Creating Value for Microenterprises through Collaboration and Innovation. Technology Innovation Management Review, 3(11): 37-42. http://timreview.ca/article/744

Ståhlbröst, A., \& Holst, M. 2013. The Living Lab Methodology Handbook. Danish Agency for Science Technology and Innovation, Lietuvos Mokslo Taryba, The Research Council of Norway, Norden NordForsk, Rannís and Vinnova.

http://www.ltu.se/cms_fs/1.101555!/file/LivingLabsMethodologyB ook_web.pdf

von Hippel, E. 1976. The Dominant Role of Users in the Scientific Instrument Innovation Process. Research Policy, 5(3): 212-239. https://doi.org/10.1016/0048-7333(76)90028-7

von Hippel, E. 2005. Democratizing Innovation. Cambridge, MA: The MIT Press.

Yin, R. K. 2003. Case Study Research: Design and Methods (3rd ed.). Thousand Oaks, CA: Sage. 


\section{Academic Affiliations and Funding Acknowledgements}

Canadà
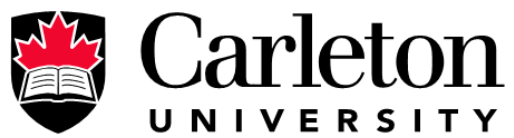

U N I V E R S I T Y

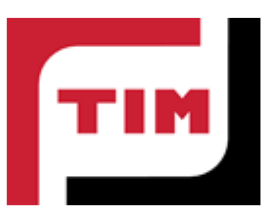

The Federal Economic Development Agency for Southern Ontario (FedDev Ontario; feddevontario.gc.ca) is part of the Innovation, Science and Economic Development portfolio and one of six regional development agencies, each of which helps to address key economic challenges by providing regionallytailored programs, services, knowledge and expertise.

- The TIM Review receives partial funding from FedDev Ontario's Investing in Regional Diversification initiative.

Technology Innovation Management (TIM; timprogram.ca) is an international master's level program at Carleton University in Ottawa, Canada. It leads to a Master of Applied Science (M.A.Sc.) degree, a Master of Engineering (M.Eng.) degree, or a Master of Entrepreneurship (M.Ent.) degree. The objective of this program is to train aspiring entrepreneurs on creating wealth at the early stages of company or opportunity lifecycles.

- The TIM Review is published in association with and receives partial funding from the TIM program. 